\title{
EGZORCYZMY W NOWYM TESTAMENCIE
}

Wypędzanie złych duchów, ich egzorcyzmowanie, było niewątpliwie specyficzną cechą działalności Jezusa Chrystusa ${ }^{1}$. Pan Bóg dla ustalenia pokoju, to jest wspólnoty z sobą, oraz dla zespolenia braterskiej społeczności wśród ludzi, i to grzesznych, postanowił wkroczyć w historię ludzką w sposób nowy i ostateczny posyłając Syna swego w ludzkim ciele, aby przez Niego uwolnić ludzi spod władzy ciemności i szatana (por. Kol 1,13; Dz 10,38) oraz pojednać w Nim świat ze sobą (por. 2 Kor 5,19)². Święty Jan Apostoł wyraźnie poucza, iż Syn Boży objawił się po to, aby zniszczyć dzieła diabła (por. $1 \mathrm{~J} 3,8$ ).

\section{DZIALALNOŚĆ JEZUSA CHRYSTUSA}

Trzej ewangeliści synoptyczni przekazali opis kuszenia Jezusa na pustyni przez szatana (por. Mt 4,1-11; Mk 1,12-13; Łk 4,1-13). Po chrzcie Jezus przebywał na pustyni czterdzieści dni i nocy, a kiedy poczuł głód, podszedł do Niego kusiciel i doświadczał Go, wystawiając na próbę. W walce z szatanem Chrystus nie chciał ulec słabościom obciążającym człowieka. Chrystus, przyjąwszy ciało, nie był wolny od diabelskich pokus. Walka, która zarysowuje się w opisie kuszenia, uzmysławia nam jak wielkiego przeciwnika widział szatan w Chrystusie, skoro już na samym początku Jego działalności, atakuje Go tak zuchwale. Diabeł czuł zagrożenie swego panowania. Szatan, ,władca tego świata” (J 12,31), nie oszczędza również Chrystusa, Syna Bożego i poddaje Go największym pokusom. Pierwszą z tych pokus była pokusa ciała, którą Chrystus odczuwał w chwili głodu:

Por. J.K. Howard, Egzorcyzm, w: Stownik wiedzy biblijnej, red. M. Metzger, M. Coogan, Pallotinum, Warszawa 1997, s. 143-144.

2 Por. DM 3; Ch. Schönborn, Bóg zesłat Syna swego. Chrystologia, Pallotinum, Poznań 2002, s. 66; O. Gonzáles de Cardenal, Cristología, Biblioteca de Autores Cristianos, Madrit 2006, s. 504-505. 
„Jeżeli jesteś Synem Bożym, powiedz temu kamieniowi, żeby stał się chlebem” (Łk 4,3). Jezus stanowczo odpowiada słowami Księgi Powtórzonego Prawa, iż nie samym chlebem żyje człowiek $(8,3)$. Szatan nie daje za wygraną, kusząc Chrystusa pokusą chwały. Boży Syn ma rzucić się w dół z narożnika świątyni, aby aniołowie uchwycili Go i nie pozwolili Mu upaść. I tym razem Chrystus odpowiada słowem Bożym: „Napisane jest: 'Nie będziesz wystawiał na próbę Pana, Boga Swego"' (Pwt 6,16; Łk 4,12). Ostatnią pokusą, której użył szatan, była pokusa sprawowania rządów nad światem. Diabeł, pokazując Chrystusowi królestwa świata, mówi: „Tobie dam potęgę i wspaniałość tego wszystkiego, bo mnie są poddane i mogę je odstąpić komu chcę. Jeśli więc upadniesz i oddasz mi pokłon, wszystko będzie Twoje" (Łk 4,6-7). Pan Jezus zwycięża i tę pokusę. Stanowczo odrzuca od siebie złego ducha, rozkazując: „Idź precz szatanie! Jest bowiem napisane: 'Panu, Bogu swemu, będziesz oddawał pokłon i Jemu samemu służyć będziesz"” (Mt 4,10).

Szatan stawiał Chrystusa w sytuacjach, w których pokusa i próba zbiegły się razem. Takiej próby nie wytrzymał Adam i naród wybrany. „Ewangeliści wskazują na zbawcze znaczenie tego tajemniczego wydarzenia. Jezus jest nowym Adamem, który pozostaje wierny tam, gdzie pierwszy Adam uległ pokusie. Jezus doskonale wypełnia powołanie Izraela, w przeciwieństwie do tych, którzy prowokowali niegdyś Boga przez czterdzieści lat na pustyni. W tym Jezus jest zwycięzcą diabła; związał mocarza, aby odebrać mu jego zdobycze. Zwycięstwo Jezusa nad kusicielem na pustyni uprzedza zwycięstwo męki, w której Jezus okazał najwyższe posłuszeństwo swojej synowskiej miłości do Ojca"4. Na pustyni kusiciel poniósł

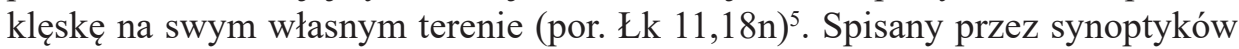
fragment o „kuszeniu Jezusa” jest źródłem informacji mówiących o naturze diabła. Przede wszystkim wskazuje na szatana jako tego, który przeciwstawia się Bogu. W konsekwencji grzechu ludzie popadają w zależność od władzy szatana rządzącego ogromnym królestwem (por. Mt 12,26; Ap 13,2). Święty Jan poucza, że „kto grzeszy, jest dzieckiem diabła" (1 J 3,8). Panowanie złego ducha jest powszechne, o czym mówi List do Rzymian: „Jesteście niewolnikami tego, komu dajecie posłuch” $(6,16)$, a Drugi List św. Piotra tę prawdę ujmuje mówiąc: „komu bowiem kto uległ, temu też służy jako niewolnik" $(2,19)$. Chrystus sam nazywa szatana „władcą tego świata” (J 12,31), a św. Paweł posuwa się jeszcze dalej i nazywa go „bogiem tego świata” (2 Kor 4,4).

Por. R. Laurentin, Szatan mit czy rzeczywistość?, Instytut Wydawniczy PAX, Warszawa 1998, s. 36-37; R. Czerwiński, Metody stosowane przez złego ducha na podstawie konfrontacji Jezusa z szatanem (Mt 4, 1-11 i par.), „Studia Warmińskie”, 51(2014), s. 83-87.

4 Por. KKK 536.

5 Por. J. Corbon, Próba - pokusa, w: Stownik teologii biblijnej, red. X. Leon-Dufour, Pallotinum, Poznań 1994, s. 797. 
Objawienie poucza nas również, iż szatan jest przywódcą złych duchów (Mt 9,34) i jest pierwszy wśród upadłych aniołów6 ${ }^{6}$. Władzę, którą szatan ma nad światem, opisuje także Apokalipsa przedstawiając go jako smoka na tronie $(2,13)$ w diamentowej koronie. Z księgi tej dowiadujemy się, iż szatan ma moc i wielką władzę $(13,2)$. W omawianym fragmencie diabeł jawi się jako kusiciel, podstępny jak w Edenie (por. Rdz 3,1-3). Szatan sprowadza ludzi z drogi prawej (por. 1 Tym $5,15)$, próbując pozbawić Chrystusa panowania. Tak przewrotny duch używa podstępu. Tej broni użył w walce z Chrystusem, któremu jednak znane są knowania szatańskie (por. 2 Kor 2,11). Demon jest kłamcą i ojcem kłamstwa (por. J 8,44), i przybiera różne postacie, by zgubić swe ofiary, jest jak wilk w owczej skórze (por. Mt 7,15). Chociaż szatan jest aniołem ciemności, potrafi podawać się za anioła światłości (por. 2 Kor 11,14), zwodzi, oszukuje i prowadzi na manowce całe narody (por. Ap 19,2; 20,2; 7,10). Szatan, kłamca (por. J 8,44), co można łatwo zauważyć, jest wyraźnie przeciwnikiem i przeciwieństwem Chrystusa Prawdy (por. J 14,6)7. Fragment o Kuszeniu Chrystusa nie jest tylko ukazaniem przeciwstawienia Chrystusa diabłu. Fragment ów pozwala uświadomić sobie absolutność władzy Zbawiciela nad złym duchem. Pan Jezus nie daje diabłu żadnej możliwości zaczepki, jest bez grzechu (por. Hbr 4,15) i nie ma nic wspólnego ze złem. Sam Chrystus mówi: ,władca tego świata. Nie ma on jednak nic swego we Mnie" (J 14,30). Chrystus, rozkazując szatanowi odejść, ukazuje moc, z jaką działa i tryumf w sytuacji, w której inni ludzie upadają ${ }^{8}$.

Ewangelie przedstawiają życie Jezusa jako walkę z szatanem, zaś stawką walki jest ostateczne zbawienie człowieka. Zmaganie zaczyna się od sceny kuszenia, kiedy to po raz pierwszy od czasów w raju człowiek, przedstawiciel całej ludzkości ,syn Adama” (Łk 3,38), znajduje się twarzą w twarz z diabłem9. Wyrazem tej walki jest również uzdrowienie opętanych, będące dowodem, że „Królestwo Boże już przyszło" (Mk 3,22), a królestwo szatana skończyło się (por. Łk 10, 17-20). ${ }^{10}$ „Jezus określa koniec rządu złego ucisku i początek nowej wolności dla ludzi, jako że jest On wyzwolicielem" "W dalszej części przedstawione zostaną sceny

6 Por. P. Szuppe, Szatan w Biblii, „Collactanea Theologica” 75(2005)1, s. 49; M. Parchem, Rola Michała w przekazach o ,buncie w niebiosach” oraz , upadku aniołów”, w: Michat Archaniot, t. I: Zagadnienia teologiczne, red. H. Oleschko, S. Łącki, Michalineum, Marki 2012, s. 126.

7 Por. A. Skowronek, Aniołowie sa wśród nas. Fascynacje - Dociekania - Wierzenia, Biblioteka Więzi, Warszawa 2002, s. 113-115; T. Stępień, Doktor anielski o aniołach, Towarzystwo „Powściągliwość i Praca", Warszawa 2014, s. 120-121.

8 Por. C. Spisq, Istnienie diabła jako element nowotestamentalnego Objawienia, w: Zło w świecie (Kolekcja „Comunio”, t. 7), red. L. Balter, Pallotinum, Poznań 1992, s. 25-26.

9 M. Kehl, „I widziat Bóg, że to jest dobre”. Teologia stworzenia, W drodze, Poznań 2008, s. 428-429; P. Szuppe, Szatan w Biblii, dz. cyt., s. 64.

10 G. Witaszek, Biblia o szatanie, w: Teologia o szatanie, red. K. Góźdź, Wydawnictwo KUL, Lublin 2000, s. 29.

11 Tamże, s. 35. 
z ewangelii ukazujące egzorcyzmy dokonane przez Pana Jezusa. Egzorcyzmy były bowiem stałym elementem Jego posługiwania.

\section{Opętany z synagogi w Kafarnaum (Mk 1,23-28; paral. Łk 4,31-37)}

W szabat Jezus przybył do synagogi, w której przebywał człowiek opętany, dręczony przez ducha nieczystego. Na widok Chrystusa duch ustami opętanego zaczął wołać: „Czego chcesz od nas, Jezusie Nazarejczyku? Przyszedłeś nas zgubić. Wiem, kto jesteś, Święty Boży” (24). Chrystus rozkazał surowo: „Milcz i wyjdź z niego" (25). Reakcja złego ducha na słowa Jezusa była natychmiastowa. Demon, jak relacjonuje ewangelista, zaczął targać opętanym i opuścił go z przeraźliwym krzykiem. Literatura rabinistyczna świadczy, że egzorcyzmy były znane w ówczesnym świecie żydowskim i były długie oraz skomplikowane. Na uwagę zasługuje fakt, że Jezus jednym zdaniem nakazuje złemu duchowi, by opuścił nękanego człowieka ${ }^{12}$. „Ten widok wprawił w zdumienie wszystkich przyglądających się ludzi, pytali się bowiem nawzajem: Co to jest? Nowa jakaś nauka z mocą" (27). Jezus zadziwia swoją władzą, duchom nieczystym rozkazuje i są mu posłuszne (27). Opętaniu towarzyszy ostry wyraz sprzeciwu przeciwko działaniu Boga i uzewnętrzniającej się w Chrystusie mocy. Wyznanie opętanego skierowane przeciwko Chrystusowi: „Przyszedłeś nas zgubić?”, jest dokładnym odpowiednikiem mocy objawiającej się w Jego działaniu. Świadkowie egzorcyzmu odczytują działanie Jezusa jako objawienie nowej, niespotykanej mocy i nauki ${ }^{13}$. W relacjach dotyczących egzorcyzmów wyczuwa się atmosferę walki, w odróżnieniu od relacjonowanych przez ewangelistów uzdrowień. Uwidacznia się też pewien schemat: zły duch odzywa się do Chrystusa; przyjmuje postawę obronną; czuje zbliżającego się Mesjasza. Po rozkazie wyjścia szatan, o ile to możliwe, próbuje się bronić, targa opętanym, krzyczy jego ustami. W końcu przegrywa i ustępuje ze złością. Schemat ten ukazuje, jak trudno pokonać złego, który się broni. Nie na żarty jest również walka, którą wytacza szatanowi Chrystus. Niewątpliwie egzorcyzm i ukazana władza Jezusa nad szatanem jest znakiem Królestwa Bożego (por. Mk 1,15) ${ }^{14}$. Chrystus nie dyskutuje z duchem nieczystym, lecz nakazuje mu stanowczo: „Milcz i wyjdź z niego” (25).

\section{Opętany z Gerazy (Mk 5,1-20; paral. Mt 8,28-34; Lk 8,26-39)}

Egzorcyzmowanie Gerazeńczyka to kolejny opis ewangeliczny, któremu poświęcona zostanie uwaga. „Zarówno wersja Marka, Łukasza jak i Mateusza podkreśla, że uzdrowienie opętanego miało miejsce na wschodnim brzegu jeziora Genezaret, można zlokalizować je na południu Kursi, gdzie też znajduje się zbo-

12 Por. B. Maggiori, dz. cyt., s. 36.

13 Por. H. Muszyński, Uzdrowienie opętanego, w: Studio lectionem facere, red. F. Grygielewicz, Wydawnictwo KUL, Lublin 1978, s. 163.

14 Por. B. Maggiori, dz. cyt., s. 36. 
cze okalające wodę jeziora"15, w krainie pogańskiej. W te okolice przybył Chrystus i zaraz po wyjściu z łodzi przybiegł do Niego człowiek opętany i Mu się pokłonił. Człowiek ów mieszkał w grobach. Ludzie wiązali go w pęta i łańcuchy (4), by w jakiś sposób zapanować nad nim. Na nic się jednak zdały te zabiegi, ponieważ opętany łańcuchy kruszył, a pęta rozrywał, i nikt nie zdołał go poskromić (4). Nadludzka siła opętanego sprawiała wiele kłopotów. Na widok Chrystusa zły duch ustami mężczyzny zapytał: „Czego chcesz ode mnie? i prosił: nie dręcz mnie” (7). Demon zapytany przez Jezusa o imię, odpowiada: „Legion, bo jest nas wielu” (9) ${ }^{16}$. Okazuje się, że jest ich wielu. Demony próbują prawdopodobnie zastraszyć Chrystusa, podając tak wielką liczbę, jest to próba samoobrony. Czując jednak wielkość Chrystusa proszą Go, by mogły wejść w trzodę pasących się nieopodal świń. Pan Jezus pozwala na to, a opętane zwierzęta ruszyły do jeziora i potonęly. Demony pragną pozostać na ziemi, by działać zwodniczo. Wydaje się, że odczuwają to jako swego rodzaju wyrwanie ich z piekła, quasi-ucieczkę. Uciekają przed swym nieszczęściem, dzieląc je ze swymi ofiarami. Jest to sadystyczna satysfakcja ${ }^{17}$. Natomiast motyw utonięcia świń ilustruje porażkę demonów, manifestację uwolnienia ${ }^{18}$. Okoliczna ludność, przerażona, prosi Chrystusa, by odszedł z ich granic, natomiast uwolniony człowiek prosił Jezusa, żeby mógł zostać przy Nim (18). Zaskakująca może być odpowiedź Jezusa, który nie zgodził się na przyłączenie, lecz powiedział: „Wracaj do swoich, i opowiadaj im wszystko, co Pan ci uczynił i jak ulitował się nad tobą" (19). W opowiadaniu tym ujawnia się pewna stała osnowa egzorcyzmów, otóż ducha złego ciężko pokonać i nie jest w stanie tego uczynić człowiek, jest jednak ktoś, kto jest mocniejszy, którego słowa mają moc i nie może im się przeciwstawić szatan - to oczywiście Chrystus ${ }^{19}$. Jezus po raz kolejny użył imperatywnej formy egzorcyzmu: „Wyjdź, duchu nieczysty z tego człowieka” (8).

\section{Opętany epileptyk (Mk 9,14-29; paral. Mt 17,14-21; Lk 9,37-42a)}

Podjęta zostanie teraz analiza egzorcyzmu, którego dokonał Pan Jezus nad opętanym chłopcem. Sytuacja, w której do niego dochodzi, miała miejsce po Przemienieniu. Gdy Jezus przybył do swoich uczniów, a zastał ich rozprawiających z uczonymi w Piśmie, podszedł do Niego mężczyzna, którego syn miał ducha niemego. Syn ów często porywany był przez złego ducha, upadał, zgrzytał zębami i drętwiał. Zdesperowany ojciec uskarżał się, iż prosił już wcześniej o uwolnienie uczniów Pańskich, lecz oni okazali się bezradni. „Kiedy przyprowadzono opęta-

15 T. Hergesel, Jezus cudotwórca, Księgarnia św. Jacka, Katowice 1987, s. 135.

16 Tamże, s. 135. „W świadomości ówczesnego Palestyńczyka „legion” kojarzył się ze znaną powszechnie rzymską jednostką militarną, która - po reformie Mariusza - składała się z 6000 żołnierzy".

17 R. Laurentin, dz. cyt., s. 27.

18 Por. T. Hergesel, dz. cyt., s. 136.

19 Por. B. Maggiori, dz. cyt., s. 38-39. 
nego, na widok Jezusa duch zaraz począł szarpać chłopca, tak że upadł na ziemię i trząsł się z pianą na ustach" (20). Szatan już od dzieciństwa próbował zniszczyć chłopca, „wrzucał go nawet w ogień i w wodę” (22). Chrystus poproszony o pomoc stwierdza, iż „wszystko jest możliwe dla tego, kto wierzy” (24). Po czym nakazał duchowi: „Duchu niemy i głuchy rozkazuję ci, wyjdź z niego i nie wchodź w niego więcej!” (25). Duch zaczął targać chłopcem i z wielkim krzykiem wyszedł z niego. Czyn ów wprawił w zdumienie uczniów, którzy nie mogli dokonać egzorcyzmu wcześniej. Chrystus poucza ich, iż „ten rodzaj można wyrzucić tylko modlitwą i postem" (29). To końcowe wyjaśnienie, skierowane do uczniów, różni się w sposobie od egzorcyzmów przeprowadzanych przez Jezusa, który uwalnia od złego ducha mocą swojego słowa. Stwierdzenie to jednak jest receptą na sprawowanie egzorcyzmów chrześcijańskich dla sprawujących tę posługę ${ }^{20}$. Przełomowe w dokonaniu egzorcyzmów okazuje się zawierzenie Chrystusowi i silna wiara. W tym przypadku wiara ojca, pełna pokory, wymagana przez Chrystusa, pozwala na zwyciężenie złego ducha ${ }^{21}$., Wiara jest jedyną drogą pokonania szatana, gdyż zwycięstwo nad demonami jest rzeczą Boga, nie człowieka: człowiek może mieć w nim udział dzięki wierze i posłuszeństwu. Dlatego egzorcysta musi uciekać się do modlitwy, nie może polegać na własnej sile, ale tylko na potędze Boga. (...) Tyrania szatana traci swą siłę i ginie nieodwracalnie tam, gdzie napotyka na posłuszeństwo i wiarę, odnajduje natomiast całą swą moc, gdy człowiek pokłada ufność w samym sobie" 22 . Frapujący dla wielu uczonych może być fakt, że objawy, jakie miał chłopiec, przypisuje się często epilepsji. Obce są jednak dla tej choroby: niemota (17), skłonności samobójcze (rzucanie się w ogień, czy w wodę) (22), reakcje na widok egzorcysty, krzyki i wstrząsy podczas obrzędu, mówienie demona ustami człowieka ${ }^{23}$. Przedstawiona historia pozwala wysnuć wniosek, że szatan może ukrywać się „pod płaszczem” choroby.

\section{Córka Syrofenicjanki (Mk 7,24-30; paral. Mt 15,21-28)}

Egzorcyzm, któremu zostanie teraz poświęcona uwaga, to uwolnienie córki kobiety Kananejskiej. Gdy Jezus przybył w okolice Tyru i Sydonu, pewna kobieta błagała Go, żeby złego ducha wyrzucił z jej córki (26). Chrystus przez wzgląd na wielką wiarę niewiasty ulitował się i dokonał egzorcyzmu, mimo że kobieta nie była Izraelitką. Zaskakujący jest fakt nieobecności osoby opętanej przy obrzędzie. Kananejka, dopiero kiedy przyszła do domu, przekonała się o uwolnieniu, zobaczyła dziecko leżące w łóżku i to, że zły duch odszedł (30). Ewangelista nie opisuje żadnego symptomu opętania. Pozornie wydaje się więc ten przypadek mało pouczający. Znamienne jest jednak podkreślenie głębokiej ufności w moc Pana

20 Por. T. Hergesel, dz. cyt., s. 138.

${ }^{21}$ R. Laurentin, dz. cyt., s. 25.

22 B. Maggiori, dz. cyt., s. 43.

23 Por. R. Laurentin, dz. cyt., s. 24. 
Jezusa. Okazuje się również możliwe sprawowanie egzorcyzmów na odległość, bez bezpośredniego udziału osoby opętanej ${ }^{24}$.

\section{Kobieta pochylona (Lk 13,10-17)}

W szabat, gdy Chrystus nauczał w synagodze, zobaczył kobietę, która od osiemnastu lat miała ducha niemocy (10). Niewiasta, na skutek szatańskiego działania, była pochylona i nie mogła się wyprostować. Pan Jezus zawołał ją do siebie i powiedział: „Niewiasto jesteś wolna od swej niemocy” (12) i „włożył na nią ręce” (13). Jak relacjonuje to wydarzenie św. Łukasz, kobieta „natychmiast wyprostowała się i ogarnięta wielką radością chwaliła Boga” (13). Ten krótki fragment uświadamia obserwatorom wydarzenia, że diabeł przez wiele lat potrafi trzymać człowieka w swej mocy. Szatan osiemnaście lat trzymał ową kobietę na uwięzi (17). Znamienne jest, że ewangelista Łukasz, który był lekarzem (por. Kol 4,14), wyraźnie odróżnia tutaj opętanie od innej choroby.

\section{Inne świadectwa}

Obok tych egzorcyzmów, które bardziej zostały wyeksponowane przez synoptyków, znajdujemy jeszcze wiele innych świadectw sprawowania tego obrzędu przez Jezusa. Jednym z nich jest egzorcyzmowanie opętanego niemowy. „Raz przyprowadzono $\mathrm{Mu}$ niemowę opętanego". Po wyrzuceniu złego ducha, niemy odzyskał mowę (Mt 9,32-34; por. 12,22; Łk 11,14). Również Maria Magdalena doznała uwolnienia mocą sprawowanych przez Jezusa egzorcyzmów, gdyż była opętana przez siedem złych duchów (por. Łk 8,2; Mk 16,9). Po wyzwoleniu od złych duchów Maria stała się oddaną uczennicą Pańską, chodziła za Mistrzem. Jej wiara zaprowadziła ją aż na Kalwarię. Ewangelie ukazują egzorcyzm jako stały element posługi Chrystusa. „Gdy Jezus przebywał w Kafarnaum z nastaniem wieczora, gdy słońce zaszło, przynosili do Niego chorych i opętanych; i całe miasto było zebrane u drzwi. Uzdrowił wielu dotkniętych rozmaitymi chorobami i wiele złych duchów wyrzucił, lecz nie pozwalał złym duchom mówić, ponieważ wiedziały, kim On jest" (Mk 1,32-34; por. Mt 8,16; Łk 4,40-41). Na uwagę zasługuje tutaj fakt, że ewangelista wyraźnie odróżnia opętania od chorób. Jezus zabraniał też mówić demonom, kim On jest (por. Mk 3,10-12; Łk 4,41-42).

Faryzeusze i uczeni w Piśmie zarzucali Jezusowi, że ma Belzebuba i przez władcę złych duchów wyrzuca złe duchy (por. Mk 3,22). Jezus podejmuje z nimi dyskusję i podaje swoją teologię egzorcyzmów (por. Mk 3,20-30), nie chce bowiem, by znaki, które dokonuje, były opacznie rozumiane i thumaczone. Przeciwnicy Jezusa nie mogą zanegować Jego dzieł, „ograniczają się niejako z konieczności do zdyskwalifikowania Jego osoby i dzieła: nic innego już im nie pozostaje. Twierdzą więc, że działania Jezusa są zwykłą magią, mającą zwieść thumy. Przez

${ }^{24}$ Por. G. Amorth, Egzorcyści i psychiatrzy, Edycja Świętego Pawła, Częstochowa 1999, s. 30. 
władcę złego ducha wyrzuca złe duchy (por. Mk 3,22). Co więcej, On sam jest opętany („ma Belzebuba” - Mk 3,22)”25, Jezus tłumaczy, że wyrzuca złe duchy mocą Ducha Świętego i jest to dowodem na nadejście Królestwa Bożego do ludzi (por. Mt 12,25-28). Szatan, mimo swej mocy i poczucia swej własnej siły, został zwyciężony przez Jezusa (por. Mt 12,29). Odtąd już egzorcyzmy będą dokonywane w imię Jezusa ${ }^{26}$. Chrystus zapytuje faryzeuszy: „I jeśli Ja przez Belzebuba wyrzucam złe duchy, to przez kogo wyrzucają je wasi synowie" (Mt 12,27). Słowa Chrystusa odsłaniają prawdę, że synowie Izraela znali egzorcyzmy i praktykowali je.

Ewangelia św. Jana nie mówi o egzorcyzmach. Podczas działalności publicznej Jezus nie dokonuje egzorcyzmów. Podczas ostatniej wieczerzy Jezus powiedział: „Już nie będę z wami wiele mówił, nadchodzi bowiem władca tego świata. Nie ma on jednak nic wspólnego we Mnie" $(14,30)$. Zdanie to zaznacza wyraźną odrębność Jezusa, Jego dystans od szatana, ich przeciwieństwo. Również czyn Judasza, pojmowany jako dzieło diabła, uwidacznia tą antytezę. Jezus, gdy ujawnił zdradę Judasza, doznał głębokiego wzruszenia (por. J 13,21), a miało to miejsce podczas spożywania wieczerzy, gdy diabeł już nakłonił serce Judasza Iskarioty, syna Szymona, aby Go wydać $(13,2)^{27}$. „Szatan wszedł w Judasza, gdy ten przyjął kawałek chleba dany mu przez Jezusa" (J 13,27) i natychmiast potem „wyszedł z wieczernika z zamiarem, by zdradzić Jezusa" $(\mathrm{J} 13,30)$. Prawdziwym przeciwnikiem jest ten, który opiera się misji Jezusa, ten kto nie chodzi w prawdzie, i od samego początku jest kłamcą i zabójcą (por. J 8,44). Dlatego nieprzyjaciele Jezusa są uważani za synów diabła, ponieważ odrzucili prawdę o Jezusie i walczyli przeciwko Niemu, doprowadzając do śmierci ${ }^{28}$. Przy grobie Łazarza Chrystus wzruszył się w duchu, rozrzewnił (por. J 11,33), cierpiał bowiem z powodu śmierci, która pojmowana była jako zwycięstwo szatana. Jezus zawołał donośnym głosem: „Łazarzu wyjdź na zewnątrz!” (J 11,43). Potężny głos objawia siłę Zbawiciela, która usuwa śmierć i tym samym zadaje śmierć szatanowi²9.

\section{UCZNIOWIE KONTYNUATORAMI MISJI JEZUSA}

Jak można dowiedzieć się z Ewangelii, Jezus wysyłał uczniów, by głosili Królestwo Boże. Apostołowie otrzymali od Chrystusa władzę uzdrawiania i egzorcyzmowania. „Jezus przywołał do siebie Dwunastu i zaczął ich wysyłać po dwóch. Dał im też władzę nad duchami nieczystymi” (Mk 6,7). „Dał im moc i władzę nad

25 B. Maggiori, dz. cyt., s. 44.

26 Por. J. B. Brunon, P. Grelot, Demony, w: Stownik teologii biblijnej, dz. cyt., s. 206.

27 Por. E. Szymanek, Wyktad Pisma Świętego Nowego Testamentu, Pallottinum, Poznań 1990, s. 91.

28 G. Witaszek, Biblia o szatanie - rzeczywistość czy mit?, w: Teologia o Szatanie, dz. cyt., s. 34.

29 Por. E. Szymanek, dz. cyt., s. 92. 
wszystkimi złymi duchami i władzę leczenia chorób" (Łk 9,1). Łukasz czyni tutaj wyraźne rozgraniczenie między uzdrowieniem a opętaniem. Uczniowie po swym powrocie mówili do Jezusa: „Panie przez wzgląd na Twoje imię nawet złe duchy nam się poddają" ( $Ł k 10,17)$, a jest to wyrazem klęski szatana. Uczniowie jeszcze za życia Jezusa uwalniali od złego ducha. Obok nich działali też inni egzorcyści (por. Mk 9,49), nie będący uczniami Pańskimi, którym Chrystus nie zakazywał działalności. Przed wniebowstąpieniem Pan zwrócił się do apostołów: „Tym zaś, którzy uwierzą te znaki towarzyszyć będą: w imię moje złe duchy będą wyrzucać" (Mk 16,17). Taki więc będzie, poprzez wszystkie wieki, jeden ze znaków towarzyszących misji uczniów Chrystusa, razem z cudami podczas głoszenia Ewangelii $^{30}$.

Apostołowie po śmierci Jezusa nie przestali egzorcyzmować, lecz posłuszni woli Mistrza, pełnili w Kościele dalej powierzoną misję. Wiele uwolnień od złego ducha relacjonują nam Dzieje Apostolskie. Gdy św. Filip działał w Samarii, głoszonym słowem porywał tłumy. Wtedy też z wielu opętanych wychodziły z donośnym krzykiem duchy nieczyste (por. Dz 8,7). Moc, z jaką działał Filip, wprowadzała ludzi w zdumienie. Apostołowie przebywając w Jerozolimie również sprawowali obrzędy egzorcyzmów. „Wielu ludzi przychodziło do nich, znosząc chorych i dręczonych przez duchy nieczyste, a wszyscy doznawali uzdrowienia" (Dz 5,26). Pośród uczniów Pana Jezusa i św. Paweł dokonywał wielu cudów, tak że ,nawet chusty i przepaski z jego ciała kładziono na chorych, a choroby ustępowały z nich i wychodziły złe duchy" (por. Dz 19,11).

Łukasz relacjonuje w Dziejach Apostolskich egzorcyzm, którego dokonano nad opętaną dziewczyną. Kobieta, o której mowa, była niewolnicą i uważano ją za wieszczkę Apollona. Kiedy Paweł i Sylas szli do prezeuchy - miejsca modlitwy, dziewczyna wołała za nimi: „Ci ludzie są sługami Boga Najwyższego, oni wam głoszą drogę zbawienia” (17). Niewiasta czyniła to przez wiele dni, nie atakowała jednak Pawła, ale przeszkadzała w głoszeniu Dobrej Nowiny. Opętana miała wieszcze siły Apollona - Pytona i należała do tzw. grupy pytones (w owym czasie istniało wiele wyroczni, sybilli; wróżono z lotu ptaka, z wnętrzności składanych ofiar). Chociaż św. Paweł uważał Apolla za ludzki wymysł (por. 1 Kor 8,4-6), to nie ignorował tego zjawiska, nie lekceważył dziewczyny, lecz widział w niej działającego szatana. Apostoł nie chciał, by potwierdzenia o autentyczności jego misji szukano w ustach opętanej dziewczyny, związanej z wyrocznią w Delfach. Paweł mając już dość natręctwa dokonał egzorcyzmu: „Rozkazuję ci w imię Jezusa Chrystusa abyś z niej wyszedł" (18). Duch zły ugina się, a uwolnienie i tym razem dokonuje się mocą imienia Jezusa Chrystusa ${ }^{31}$.

30 Por. J.B. Brunon, P. Grelot, Demony, dz. cyt., s. 206.

31 Por. J.K. Pytel, Ksiega Dziejów Apostolskich. Problemy literackie i wybrane tematy teologiczne, w: Księga Dziejów Apostolskich, red. J.K. Pytel, Ottonianum, Szczecin 1999, s. 59-60. 
Dzieje Apostolskie opowiadają także o siedmiu synach Skewasa, którzy byli wędrownymi, żydowskimi egzorcystami (por. Dz 19,13-16). Widząc sukcesy św. Pawła, uwalniającego ludzi od opętania, oni sami postanowili wzywać nad opętanymi imienia Jezusa, którego głosił Paweł. „Zaklinamy was przez Pana Jezusa, którego głosi Paweł - mówili” (13). Niestety, egzorcyzmy nie okazały się skuteczne. Zły duch nie ukazał uległości, nie znał egzorcystów, znał Jezusa i Pawła. Człowiek, w którym był zły duch, rzucił się na nich, ,powalił wszystkich i pobił tak, że nadzy i poranieni uciekli” (16).

Egzorcyzmy to nie eksperymentowanie, próba, w czyje imię można uwalniać od złego ducha, to wiara w zwycięską moc imienia Jezusa. Nie można wzywać Chrystusa, w którego się nie wierzy. Moc egzorcyzmów bierze się z bezgranicznej wiary i zaufania pokładanego w Mesjaszu. Igraszki z diabłem okazały się dla synów Skewasa opłakane, diabeł zaatakował ich rękoma opętanego i pobił.

Ukazana w Dziejach Apostolskich walka Kościoła z mocami zła przybiera różne formy, egzorcyzmy były tylko jedną z nich.

Należy stwierdzić, że apostołowie:

- występowali przeciw magii i walczyli z zabobonami (por. Dz 13,8-10; 19,18-19),

- nie pozwalali korzystać z rad duchów wróżebnych (por. Dz 16,16),

- sprzeciwiali się bałwochwalstwu polegającemu na czci demonów (por. Ap 9,20),

- potępiali fałszywą mądrość (por. Jk 3,15),

- demaskowali szatańskie teorie zwodzące ludzi (por. 1 Tym 4,1),

- zwalczali pseudocudotwórców będących na usługach Bestii (por. Ap 16,13-14) ${ }^{32}$. Szereg fragmentów Nowego Testamentu świadczy o tym, że walka z szatanem jest realną rzeczywistością, to fakt ${ }^{33}$. Walka ta nie jest łatwa. Diabeł potrafi podawać się za anioła światła (por. 2 Kor 11,14). Szatan jest w stanie żywcem schwytać człowieka i uwikłać w swoje sidła (por. 2 Tym 2,26), on jednak powinien okazać wielką przytomność i nie poddawać się zasadzkom złego ducha. Kościół, wspierany przez Ducha Świętego, dysponuje wieloma charyzmatami. Jednym z nich jest zdolność rozpoznawania duchów (por. 1 Kor 12,10), o której powinni zabiegać szczególnie egzorcyści. W Liście do Efezjan św. Paweł zachęca, by odziewać się w oręż Bożą. Oręż ta pozwoli ostać się wobec podstępnych zakusów diabła: „Nie toczymy bowiem walki przeciw krwi i ciału, lecz przeciw Zwierzchnościom, przeciw Władzom, przeciw rządcy świata tych ciemności, przeciw pierwiastkom duchowym zła na wyżynach niebieskich" (6,1. 1b-12). Apostoł silnie akcentuje też konieczność wiary, będącej jak tarcza, która pozwala zgasić wszelki pocisk szatana. Ponadto Paweł zachęca też do modlitwy i czujności, stawania w prawdzie i sprawiedliwości (por. Ef 6,14-18).

32 Por. J.B. Brunon, P. Grelot, Demony, dz. cyt., s. 206.

33 Por. M. Kehl, ,I widziat Bóg, że to jest dobre”. Teologia stworzenia, dz. cyt., s. 432-433. 


\section{PODSUMOWANIE}

Omawiając sprawę egzorcyzmów i ich śladów opisanych w Nowym Testamencie trzeba zauważyć, że Jezus sam nauczał o opętaniu. Dowodem na to jest tekst w Ewangelii według św. Marka mówiący o tym, jakie mogą być następstwa egzorcyzmu. Gdy duch nieczysty opuści człowieka, błąka się po miejscach bezwodnych, szukając miejsca spoczynku, ale nie znajduje go. Wtedy mówi: ,, 'Wrócę do swego, skąd wyszedłem', a przyszedłszy znajduje go niezajętym, wymiecionym i przyozdobionym. Wtedy idzie i bierze z sobą siedmiu innych duchów, złośliwszych niż on sam; wchodzą i mieszkają tam. I staje się późniejszy stan owego człowieka gorszy, niż był poprzedni” (12,43-45; paral. Łk 11,24-26). Pan Jezus informuje swoich słuchaczy o działaniu szatana, który opuściwszy człowieka, nie daje za wygraną. Błąka się po pustyniach, uważanych za ulubione miejsce przebywania demonów. Diabeł szuka odpoczynku, miejsca, osoby, gdzie mógłby prowadzić swe niszczycielskie plany. Po wypędzeniu, powraca do swej ofiary, w miejsce, gdzie czuł się zadomowiony. Znajdując jednak „swój dom” uprzątnięty, do swej intrygi i pomocy włącza więc inne duchy, po czym atakuje ze złośliwszymi od siebie kompanami. Pozbawiony nieba, szuka ucieczki od swego przeznaczenia piekła. W ten sposób w tryby swego postępowania wprowadza człowieka. Wniosek, który można wysunąć na podstawie słów Chrystusa jest następujący: nie można pozostawić człowieka uwolnionego od opętania samemu sobie, narażając go na kolejne ataki złego ducha.

Objawienie w Nowym Testamencie znacznie szerzej niż, w odróżnieniu od Starego, przybliża nam postać szatana i podejmowanej z nim walki. Wiele nowotestamentalnych opisów i drobnych fragmentów uzmysławia nam, kim jest zły duch walczący z człowiekiem, ten dzielący i zwodzący ludzkość przeciwnik. Zagadnienie egzorcyzmów nie jest obce autorom tej części Ksiąg Natchnionych. Wiara w Jednego Boga zdaje się być już stabilna i ugruntowana w społeczności Izraela, dlatego problem zagrożenia dualizmem, tak bardzo widoczny w Starym Testamencie, jest nieco złagodzony. Jezus Chrystus ukazany jest jako ten, który walczy z szatanem, także egzorcyzmując i ostatecznie pokonuje go na drzewie krzyża. Walkę z diabłem i jego knowaniami podjęli, posłuszni woli Chrystusa, apostołowie. Odtąd egzorcyzmy będą już stale znane i praktykowane w Kościele, a moc ich sprawowania czerpana będzie z wiary płynącej od Chrystusa, z pokornej ufności w siłę i moc Jego świętego imienia. 


\section{Bibliografia}

Amorth G., Egzorcyści i psychiatrzy, Edycja Świętego Pawła, Częstochowa 1999.

Czerwiński R., Metody stosowane przez złego ducha na podstawie konfrontacji Jezusa z szatanem (Mt 4,1-11 i par.), „Studia Warmińskie”, 51(2014), s. 81-93.

Brunon J.B., Grelot P., Demony, w: Stownik teologii biblijnej, red. X. Leon-Dufour, Pallotinum, Poznań 1994, s. 204-207.

Gonzáles de Cardenal O., Cristología, Biblioteca deAutoresCristianos, Madrit 2006.

Hergesel T., Jezus cudotwórca, Księgarnia Św. Jacka, Katowice 1987.

Howard J. K., Egzorcyzm, w: Słownik wiedzy biblijnej, red. M. Metzger, M. Coogan, Pallottinum, Warszawa 1997, s. 143-144.

Katechizm Kościoła Katolickiego, Pallotinum, Poznań 1994.

Kehl M., „I widziat Bóg, że to jest dobre”. Teologia stworzenia, W drodze, Poznań 2008.

Laurentin R., Szatan mit czy rzeczywistość?, Instytut Wydawniczy PAX, Warszawa 1998.

Maggiori B., Chrystus i szatan w Ewangelii Markowej, w: Zło w świecie, red. L. Balter, Pallottinum, Poznań 1992, s. 34-49.

Muszyński H., Uzdrowienie opętanego, w: Studio lectionem facere, red. F. Grygielewicz, Wydawnictwo KUL, Lublin 1978, s. 159-164.

Parchem M., Rola Michała w przekazach o ,,buncie w niebiosach” oraz „upadku aniołów”, w: Michat Archaniot, t. I: Zagadnienia teologiczne, red. H. Oleschko, S. Łącki, Michalineum, Marki 2012, s. 123-164.

Corbon J., Próba - pokusa, w: Stownik teologii biblijnej, red. X. Leon-Dufour, Pallotinum, Poznań 1994, s. 797.

Pytel J.K., Księga Dziejów Apostolskich. Problemy literackie i wybrane tematy teologiczne, w: Księga Dziejów Apostolskich, red. J.K. Pytel, Ottonianum, Szczecin 1999, s. 21-65.

Schönborn Ch., Bóg zesłat Syna swego. Chrystologia, Pallotinum, Poznań 2002.

Skowronek A., Aniołowie sa wśród nas. Fascynacje - Dociekania - Wierzenia, Biblioteka Więzi, Warszawa 2002.

Sobór Watykański II, Dekret o działalności misyjnej Kościoła (7 XII 1965), w: Konstytucje. Dekrety. Deklaracje, Poznań 1999, s. 436-474.

Spisq C., Istnienie diabła jako element nowotestamentalnego Objawienia, w: Zło w świecie (Kolekcja „Comunio”, t. 7), red. L. Balter, Pallotinum, Poznań 1992, s. 24-33.

Stępień T., Doktor anielski o aniołach, Towarzystwo „Powściągliwość i praca”, Warszawa 2014.

Szuppe P, Szatan w Biblii, „Collactanea Theologica” 75(2005)1, s. 47-67. 
Szymanek E., Wykład Pisma Świętego Nowego Testamentu, Pallottinum, Poznań 1990.

Witaszek G., Biblia o szatanie - rzeczywistość czy mit?, w: Biblia o szatanie, w: Teologia o szatanie, red. K. Góźdź, Wydawnictwo KUL, Lublin 2000, s. 21-42.

\section{Streszczenie}

W artykule podjęto temat egzorcyzmów w Nowym Testamencie. Egzorcyzmy były przedmiotem codziennej posługi Pana Jezusa, który ma władzę nad złymi duchami. Pan Jezus troszczył się o każdego człowieka, w tym również o osoby opętane i doświadczane przez złego ducha. Egzorcyzmowanie było też przedmiotem Jego nauczania. Objawienie zawarte w Nowym Testamencie w sposób znacznie szerszy przybliża, w odróżnieniu od Starego Testamentu, postać szatana, jego naturę i sposób działania. Chrystus ostatecznie pokonuje złego ducha na drzewie krzyża. Walkę z demonami podjęli, zgodnie z wolą Chrystusa, Jego uczniowie. Odtąd praktyka egzorcyzmów na stałe weszła do posługi Kościoła, który moc do ich sprawowania czerpie z wiary płynącej od Chrystusa.

Słowa kluczowe: egzorcyzmy, szatan, postuga Chrystusa, uwolnienie

\section{Exorcisms in the New Testament}

\section{Summary}

The article discusses the topic of exorcism as presented in the New Testament. Exorcisms were a part Jesus' mission and he had the power over the evil spirits. Our Lord cared for every human being, including those possessed and tormented by the devil. He also taught about the practice of exorcism. Unlike the Old Testament, the revelation in the New Testament reveals much more about Satan, his nature, and his way of working. Jesus finally overcame the malign ghost on the Tree of the Cross. The fight against the demons was taken up by his disciples in accordance with the will of Christ. Since then the practice of exorcism has become a permanent part of the Church ministry and she draws the strength to perform the exorcisms from the faith received from Christ.

Keywords: exorcism, Satan, ministry of Christ, salvation 